\title{
STUDI KOMPARATIF HASIL BELAJAR SISWA MENGGUNAKAN \\ PENDEKATAN KONTEKSTUAL DENGAN PENDEKATAN \\ KONVENSIONAL PADA MATA PELAJARAN EKONOMI \\ DI SMA NEGERI 1 LUBAI TAHUN PELAJARAN 2015/2016
}

\author{
Oleh: Januardi \\ (UNIVERSITAS PGRI PALEMBANG) \\ januardibkl@gmail.com
}

\begin{abstract}
Abstrak
Pendekatan pembelajaran kontekstual merupakan pendekatan kontemporer, sedangkan pendekatan konvensional dimaksudkan pendekatan pembelajaran yang sudah digunakan sejak waktu yang lama. Penelitian ini dilakukan untuk mengetahui keefektifan penggunaan pendekatan kontekstual dalam proses pembelajaran. Metode penelitian yang digunakan adalah eksperimen Terdapat dua variabel dalam penelitian ini disimbolkan dengan $X_{1}$ dan $X_{2}$. Pengujian hipotesis menggunakan uji $t$, yang diketahui bahwa hasil belajar siswa menggunakan kedua pendekatan memiliki perbedaan yang cukup signifikan, yang berarti pendekatan kontekstual efektif digunakan dalam proses pembelajaran ekonomi di SMA Negeri 1 Lubai.
\end{abstract}

Kata Kunci: $\quad$ Komparatif, Hasil Belajar, Pendekatan Kontekstual, Pendekatan Konvensional, Ekonomi.

\section{COMPARATIVE STUDY OF STUDENT LEARNING RESULTS USING CONTEXTUAL APPROACH WITH CONVENTIONAL APPROACH TO ECONOMIC LESSONS IN LUBAI 1 STATE HIGH SCHOOL 2015/2016}

\begin{abstract}
The contextual learning approach is a contemporary approach, while the conventional approach is intended to be a learning approach that has been used for a long time. This research was conducted to determine the effectiveness of the use of contextual approaches in the learning process. The research method used is experimental There are two variables in this study symbolized by X1 and X2. Testing the hypothesis using the $t$ test, which is known that student learning outcomes using both approaches have significant differences, which means that contextual approaches are effectively used in the process of learning economics in SMA 1 Lubai.
\end{abstract}

Keywords: Comparative, Learning Outcomes, Contextual Approaches, Conventional Approaches, Economics. 


\section{PENDAHULUAN}

Pendidikan merupakan salah satu hal penting dalam kehidupan masa kini, bahkan sebagian masyarakat rela untuk mengeluarkan biaya yang tidak sedikit untuk memperoleh pendidikan yang berkualitas. Pendidikan hakikatnya memberikan pengaruh positif kepada setiap orang yang menginginkan hasil yang baik melalui proses yang baik. Melalui Undangundang No. 20 tahun 2003 dijelaskan secara terperinci mengenai tujuan pendidikan, salah satunya adalah untuk membentuk manusia yang memiliki kompetensi dan berkarakter.

Untuk mencapai tujuan pendidikan tersebut beberapa cara dilakukan, salah satunya melalui pendekatan dalam proses pembelajaran. Pendekatan pembelajaran pun berkembang sesuai dengan perkembangan zaman, teknologi informasi dan kebutuhan si-pembelajar. Diawali dengan pendekatan pembelajaran ceramah, resitasi, praktik maupun latihan, yang saat ini pendekatan tersebut dikatakan sebagai pendekatan pembelajaran konvensional. Perkembangan pendekatan pembelajaran menuntun pada pendekatan pembelajaran kontekstual yang dimaksudkan bahwa keterlibatan peserta didik secara penuh dalam proses pembelajaran, sehingga peserta didik dapat memaknai proses belajar dengan cara yang lebih komprehensif.

Akan tetapi, saat ini sebagian pendidik dan peserta didik terkadang tidak memahami bahwa substansi pembelajaran tidak berubah yaitu untuk membentuk individu yang berkualitas baik secara kompetensi maupun kepribadian. Sehingga pendekatan konvensional dikatakan sebagai pendekatan yang tidak layak digunakan dalam pembelajaran saat ini, padahal beberapa materi pembelajaran masih tetap dapat menggunakan pendekatan tersebut. Berdasarkan hal tersebutlah penelitian ini dirasa penting untuk dilakukan, sebagai salah satu bentuk kepedulian dan alat untuk mendeskripsikan bahwa pendekatan konvensional masih dapat dipergunakan dalam proses pembelajaran saat ini. Hanya saja, mungkin pada materi tertentu.

Agar pemahaman mengenai penelitian ini tidak memiliki perbedaan persepsi, maka perlu dibatasi cakupan penelitian. Hasil belajar dalam penelitian ini diperoleh dari hasil tes siswa setelah pembelajaran dilakukan 
melalui pendekatan kontekstual dan pendekatan konvensional. Berdasarkan uraian di atas, maka rumusan masalah penelitian ini adalah pendekatan pembelajaran manakah yang lebih tepat digunakan dalam proses pembelajaran ekonomi berdasarkan hasil belajar yang diperoleh dan analisis uji beda ratarata?.

Tujuan utama penelitian ini adalah untuk memberikan solusi kepada pendidik, sehingga hasil belajar siswa pada mata pelajaran ekonomi dapat lebih optimal jika menggunakan pendekatan pembelajaran yang tepat. Tujuan lainnya adalah untuk memberikan sanggahan kepada insan pendidikan, meskipun pendekatan konvensional bukan berarti pendekatan tersebut tidak layak digunakan dalam proses pembelajaran masa kini.

Manfaat yang dapat diperoleh dari penelitian ini adalah guru sebagai pendidik mampu memahami karakteristik peserta didiknya, sehingga pendekatan pembelajaran yang digunakan dapat lebih tepat. Begitu pun dengan siswa, dapat mengeksplorasi pengetahuannya melalui berbagai pendekatan pembelajaran yang diterapkan. Bahkan instansi yang bersangkutan pun dapat memperoleh manfaat melalui peningkatan hasil belajar peserta didik.

\section{TINJAUAN PUSTAKA}

\section{Hasil Belajar}

Proses pembelajaran dilakukan tentunya untuk mendapatkan hasil yang maksimal, dalam proses pendidikan sering dikenal dengan istilah hasil belajar. Hasil Belajar ialah pola perbuatan, nilai, pengertian, sikap, apresiasi, abilitas dan keterampilan yang dilengkapi dengan serangkaian pengalaman (Hamalik, 2008, hal. 31).

Hamalik (2008:3) Hasil belajar mempunyai hubungan yang erat dengan belajar untuk mengetahui sejauh mana perubahan yang terjadi pada diri seseorang, baik perubahan tingkah laku dan kecakapan dapat dilihat dari hasil belajar. Hasil belajar ialah perubahan tingkah laku yang mencakup bidang apektif, kognitif, dan psikomotor yang dimiliki siswa setelah menerima pengalamannya dalam belajar (Sudjana, 2010, hal. 3).

Menurut Bloom, hasil belajar dalam rangka studi dapat dicapai melalui tiga kategori ranah yaitu kognitif, afektif, psikomotorik (Dimyati, 2009, hal. 26). Beberapa pendapat ahli menyatakan bahwa hasil 
belajar merupakan suatu hasil yang diperoleh dari suatu kegiatan belajar yang dapat dilihat dari beberapa aspek, seperti aspek kognitif, apektif maupun psikomotorik. Dan secara terperinci aspek-aspek tersebut memberikan bagian tersendiri dari sebuah penilaian yang harus dilakukan. Hasil belajar pun dapat dilihat dari proses perubahan karakter atau tingkah laku peserta didik dalam kegiatan pembelajaran.

Berdasarkan beberapa pendapat ahli tentang hasil belajar, maka dapat peneliti simpulkan bahwa hasil belajar ialah tingkat keberhasilan peserta didik dalam mencapai kemampuan yang merupakan bagian dari proses perubahan sikap atau tingkah laku siswa sebagai peserta didik karena telah mengalami secara langsung pembelajaran sehingga terdapat pengetahuan baru.

\section{Pendekatan Pembelajaran}

Pendekatan pembelajaran merupakan istilah yang digunakan dalam dunia pendidikan, yaitu suatu cara yang dilakukan oleh pendidik untuk menyampaikan materi pelajaran sehingga dapat diterima oleh peserta didik hingga akhirnya tujuan pembelajaran dapat tercapai.
Mulyatiningsih, (2012:228) menyatakan "pendekatan pembelajaran merupakan istilah yang melingkupi seluruh proses pembelajaran".

"Pendekatan pembelajaran juga didefinisikan sebagai jalan yang akan ditempuh oleh guru dan siswa dalam mencapai tujuan instruksional untuk suatu satuan instruksional tertentu" (Sagala, 2005:68). Dari kedua definisi tersebut dipahami bahwa pendekatan merupakan keseluruhan hal yang akan dilakukan dalam proses pembelajaran untuk dapat mencapai tujuan pembelajaran.

\section{Pendekatan}

Pembelajaran

\section{Kontekstual}

Pendekatan kontekstual adalah pendekatan yang menekankan pada proses keterlibatan peserta didik secara penuh untuk dapat menemukan makna dari materi yang dipelajari dan menghubungkannya dengan situasi kehidupan nyata, sehingga mendorong siswa menerapkannya dalam kehidupan sehari-hari (Sanjaya, 2011:255).

Elaine mengatakan bahwa pembelajaran kontekstual adalah "suatu sistem pembelajaran yang cocok dengan otak yang menghasilkan makna dengan menghubungkan muatan akademis 
dengan konteks dari kehidupan seharihari siswa" (Rusman, 2014:187). Jadi, berdasarkan definisi kedua ahli tersebut maka peneliti menyimpulkan bahwa pendekatan kontekstual merupakan pendekatan yang baik digunakan untuk memperoleh makna dari pembelajaran, sehingga jika dilaksanakan dengan tepat akan sangat memberikan manfaat bagi peserta didik karena peserta didik tidak hanya mengetahui melainkan memahami makna pembelajaran.

Langkah-langkah yang harus dilakukan dalam penerapan pendekatan kontekstual ini menurut Yamin, (2013:181) adalah:

a) Tahap persiapan

(1) Pendidik mengingatkan materi pelajaran yang lalu

(2) Pendidik menyampaikan tujuan pembelajaran

b) Tahap penyajian

(1) Pendidik mengemukakan masalah dalam pembelajaran, menjelaskan cara memecahkan masalah dan mengamati sesuai dengan kehidupan nyata

(2) Membuat generalisasi dan menggunakan alat untuk memecahkan masalah
(3) Peserta didik melakukan penguatan internal

(4) Pendidik memberikan dukungan untuk menghasilkan jawaban yang kritis dan kreatif

(5) Peserta didik menyimpulkan materi pembelajaran melalui solusi dari permasalahan

c) Tahap penutup

(1) Pendidik memberikan penguatan

(2) Pendidik memberikan latihan soal

(3) Pendidik beserta peserta didik menyimpulkan materi pembelajaran secara keseluruhan

Hal lain, yang merupakan bagian tidak terpisahkan dari sebuah variabel adalah kelebihan dan kekurangannya. Begitupun dengan pendekatan kontekstual memiliki kelebihan bahwa pembelajaran menjadi lebih bermakna dan rill, serta pembelajaran dapat lebih produktif. Sedangkan kelemahannya adalah pendidik diharuskan memiliki kemampuan berpikir kritis untuk selalu membimbing peserta didik. 


\section{Pendekatan}

\section{Konvensional}

Pendekatan pembelajaran konvensional dikenal juga dengan istilah pendekatan pembelajaran dengan prosedur didaktik. Kegiatan-kegiatan yang dilakukan oleh guru selama proses pembelajaran berlangsung, agar siswa dapat mencapai tujuan dengan efektif dapat dikelompokkan dalam tiga pola, yaitu pola narasi, pola perundingan bersama, dan pola pemberian tugas.

Wasno (2009:27) menyatakan bahwa pendekatan pembelajaran konvensional ini berpusat pada guru (the teacher centered aprroach). Pendekatan yang berpusat pada guru, hampir seluruh kegiatan pembelajaran dikendalikan penuh oleh guru. Seluruh sistem diarahkan kepada rangkaian kejadian yang rapi dalam lembaga pendidikan, tanpa ada usaha untuk mencari dan menerapkan pendekatan belajar yang berbeda sesuai dengan tema dan kesulitan belajar setiap individu.

$$
\text { Pendekatan konvensional }
$$

ditandai dengan guru mengajar lebih banyak mengajarkan tentang konsepkonsep bukan kompetensi, tujuannya adalah siswa mengetahui sesuatu bukan mampu untuk melakukan sesuatu, dan pada saat proses pembelajaran siswa lebih banyak mendengarkan.

Beberapa kelebihan penggunaan pendekatan pembelajaran konvensional adalah:

a) Guru mudah menguasai kelas

b) Mudah mengorganisasikan ruang kelas

c) Dapat diikuti oleh jumlah siswa yang relatif banyak

d) Mudah mempersiapkan dan melaksanakannya

e) Lebih efektif dan efisien

f) Dapat menggunakan bahan belajar yang luas

g) Dapat menguatkan bacaan peserta didik

Selain kelebihan tersebut, pendekatan konvensional juga terdapat kelemahan, yaitu:

a) Tidak dapat mengakomodir kebutuhan belajar siswa yang bertipe visual

b) Mudah membuat siswa merasa jenuh

c) Siswa cenderung pasif dalam belajar

\section{Mata Pelajaran Ekonomi}

Mata pelajaran ekonomi ialah mata pelajaran yang mempelajari tentang ilmu-ilmu ekonomi atau ilmu 
tentang prilaku dan tindakan manusia untuk memenuhi kebutuhan hidup yang bervariasi dan berkembang dengan sumber daya yang ada melalui kegiatan produksi, konsumsi, dan distribusi. Kata "ekonomi" berasal dari kata Yunani oikos yang berarti keluarga, rumah tangga dan nomos ialah peraturan, aturan, hukum, dan secara garis besar diartikan sebagai aturan rumah tangga atau manajemen rumah tangga (Wikipidea, 2012:1).

Mata Pelajaran Ekonomi ialah suatu disiplin ilmu yang mengajarkan tentang bagaimana cara manusia memenuhi kebutuhan yang tidak terbatas dengan sumber daya yang terbatas, sehingga tidak terjebak pada permasalahan ekonomi yang lebih komplek.

\section{METODOLOGI PENELITIAN}

\section{Variabel Penelitian}

"Variabel penelitian ialah segala sesuatu yang akan menjadi objek pengamatan penelitian dan kemudian untuk ditarik kesimpulan" (Sugiono, 2008:61). Penelitian ini mengkaji hubungan antara dua variabel, yaitu :

$\mathrm{X}_{1}$ : Hasil belajar siswa menggunakan pendekatan kontekstual

$\mathrm{X}_{2}$ : Hasil belajar siswa menggunakan pendekatan konvensional

\section{Definisi Operasional Variabel}

Berdasarkan uraian mengenai variabel yang digunakan dalam penelitian ini, maka untuk menghindari penafsiran ganda mengenai variabel tersebut, peneliti mendefinisikan variabel penelitian sebagai berikut:

a) Hasil belajar siswa dengan menggunakan pendekatan kontekstual ialah tingkat keberhasilan siswa dalam pencapaian hasil belajar yang diukur dari hasil tes setelah akhir pertemuan pada mata pelajaran ekonomi dengan materi pembelajaran memahami konsep ekonomi dalam kaitannya dengan permintaan, penawaran, harga keseimbangan dan pasar dengan menggunakan pendekatan pembelajaran kontekstual.

b) Hasil belajar siswa dengan pendekatan konvensional ialah tingkat keberhasilan siswa dalam pencapaian hasil belajar yang diukur dari hasil tes setelah akhir pertemuan pada mata pelajaran ekonomi dengan materi memahami konsep ekonomi dalam kaitannya dengan permintaan, penawaran, harga 
keseimbangan dan pasar dengan menggunakan pendekatan konvensional.

\section{Populasi dan Sampel}

\section{Populasi Penelitian}

Populasi dapat diartikan keseluruhan dari subjek yang akan diteliti. Populasi dalam penelitian ini ialah siswa/i kelas X di SMA Negeri 1 Lubai yang berjumlah 205 orang dan terdiri dari 6 (enam) kelas.

\section{Tabel 1. Rincian Jumlah Siswa}

\begin{tabular}{|c|c|c|c|c|}
\hline No & Kelas & $\mathrm{Lk}$ & $\operatorname{Pr}$ & Jumlah \\
\hline 1 & X.1 & 19 & 17 & 36 \\
\hline 2 & X.2 & 16 & 15 & 31 \\
\hline 3 & X.3 & 19 & 19 & 38 \\
\hline 4 & X.4 & 15 & 17 & 32 \\
\hline 5 & X.5 & 19 & 16 & 35 \\
\hline 6 & X.6 & 17 & 16 & 33 \\
\hline \multicolumn{2}{|c|}{ Jumlah } & 103 & 103 & 205 \\
\hline
\end{tabular}

Sumber : Tata Usaha SMA Negeri 1 Lubai

\section{Sampel Penelitian}

Sampel adalah bagian dari suatu populasi, sampel terdiri atas sejumlah satuan analisis yang merupakan bagian dari keseluruhan anggota populasi. Teknik pengambilan sampel dalam penelitian ini menggunakan simple random sampling. Dalam pengambilan sampel, peneliti melakukan pengambilan secara acak dari kelas populasi yang terdiri dari 6 kelas dengan asumsi kelas populasi homogen, dan hasilnya terpilih dua kelas yaitu kelas X. 5 dan X. 2. Kelas X. 5 yang diajar menggunakan pendekatan kontekstual dan kelas X. 2 yang diajar menggunakan pendekatan konvensional, seperti terlihat pada tabel berikut:

Tabel 2. Sampel Penelitian

\begin{tabular}{|c|c|c|c|c|l|}
\hline No & Kelas & Lk & Pr & $\begin{array}{c}\text { Jumlah } \\
\text { Siswa }\end{array}$ & Keterangan \\
\hline 1 & X. 5 & 19 & 16 & 35 & $\begin{array}{l}\text { Yang Belajar menggunakan } \\
\text { pendekatan kontekstual }\end{array}$ \\
\hline 2 & X. 2 & 16 & 15 & 31 & $\begin{array}{l}\text { Yang Belajar menggunakan } \\
\text { pendekatan konvensional }\end{array}$ \\
\hline \multicolumn{2}{|c|}{ Jumlah } & $\mathbf{3 5}$ & $\mathbf{3 1}$ & $\mathbf{6 6}$ & \\
\hline
\end{tabular}

\section{Metode Penelitian}

Penelitian ini adalah penelitian pendidikan, oleh karenanya metode yang digunakan pun adalah metode penelitian pendidikan. Metode penelitian pendidikan diartikan sebagai cara ilmiah untuk mendapatkan data yang valid dengan tujuan dapat ditemukan, dikembangkan, dan dibuktikan suatu pengetahuan tertentu sehingga pada gilirannya dapat digunakan untuk memahami, 
memecahkan, dan mengantisipasi masalah dalam bidang pendidikan (Sugiono, 2008:6).

Berdasarkan jenis penelitian yang dilakukan oleh peneliti maka metode yang digunakan adalah metode eksperimen, dan berdasarkan tingkat ekplanasi penelitian ini menggunakan metode deskriptif komparatif.

\section{Teknik Pengumpulan Data}

\section{Dokumentasi}

Dokumentasi digunakan untuk memperoleh data mengenai jumlah siswa, jumlah guru, dan sarana pembelajaran yang ada di lokasi penelitian.

\section{Observasi}

Teknik pengumpulan data dengan observasi digunakan jika penelitian berkenaan dengan perilaku manusia, proses kerja dan gejala-gejala alam. Observasi yang dilakukan dalam penelitian ini terdiri dari 4 indikator atau aspek yang diamati.

Tujuan menggunakan teknik observasi dalam penelitian ini adalah untuk melihat perbedaan aktivitas siswa menggunakan pendekatan kontekstual dengan pendekatan konvensional. Observer akan memberikan tanda check $(\sqrt{ })$ terhadap indikator yang tampak dan bila tidak tampak tidak diberi tanda check pada kolom lembar observasi.

\section{Tes}

Tes adalah suatu alat yang di dalamnya berisi sejumlah pertanyaan yang harus dijawab atau perintahperintah yang harus dikerjakan, untuk mendapatkan gambaran tentang kejiwaan seseorang atau sekelompok orang. Tes dalam penelitian ini digunakan untuk memperoleh data mengenai hasil belajar siswa. Tes diberikan kepada siswa setelah materi diajarkan. Tes yang diberikan kepada siswa berbentuk soal pilihan ganda. Adapun yang menjadi indikator pada tes yang diberikan adalah a) Mendeskripsikan pengertian permintaan dan penawaran; b) mengidentifikasi faktor-faktor yang mempengaruhi permintaan dan penawaran; c) menggambarkan kurva permintaan dan penawaran.

\section{Hasil Uji Coba Instrumen}

Instrumen yang akan digunakan dalam penelitian, harus diuji coba terlebih dahulu sehingga instrumen yang ada merupakan instrumen penelitian yang valid, reliabel, memiliki 
tingkat kesukaran yang layak, begitu pula dengan daya bedanya. Oleh karena itu, berikut ini hasil pengujian instrumen penelitian:

\section{Uji Coba Instrumen Tes}

Instrumen tes yang digunakan dalam penelitian ini harus diuji coba terlebih dahulu untuk mengetahui kevalidan tes tersebut, sehingga hasil penelitian dapat dipercaya kebenarannya. Berikut ini hasil perhitungan validitas tes:

TABEL 4

HASIL UJI VALIDTAS BUTIR TES

\begin{tabular}{|c|c|c|c|}
\hline No. Butir & $r_{\text {hitung }}$ & $r_{\text {tabel }}$ & Interpretasi \\
\hline \begin{tabular}{l|l}
1 \\
\end{tabular} & 0,316 & 0,294 & Valid \\
\hline 2 & 0,733 & 0,294 & Valid \\
\hline 3 & 0,769 & 0,294 & Valid \\
\hline 4 & 0.667 & 0,294 & Valid \\
\hline 5 & 0,582 & 0,294 & Valid \\
\hline 6 & 0,534 & 0,294 & Valid \\
\hline 7 & 0,380 & 0,294 & Valid \\
\hline 8 & 0,425 & 0,294 & Valid \\
\hline 9 & 0,574 & 0,294 & Valid \\
\hline 10 & 0,720 & 0,294 & Valid \\
\hline 11 & 0,465 & 0,294 & Valid \\
\hline 12 & 0,515 & 0,294 & Valid \\
\hline 13 & 0,631 & 0,294 & Valid \\
\hline 14 & 0,636 & 0,294 & Valid \\
\hline 15 & 0,574 & 0,294 & Valid \\
\hline 16 & 0,603 & 0,294 & Valid \\
\hline 17 & 0,569 & 0,294 & Valid \\
\hline 18 & 0,551 & 0,294 & Valid \\
\hline 19 & 0,649 & 0,294 & Valid \\
\hline 20 & 0,560 & 0,294 & Valid \\
\hline 21 & 0,708 & 0,294 & Valid \\
\hline 22 & 0,635 & 0,294 & Valid \\
\hline 23 & 0,700 & 0,294 & Valid \\
\hline 24 & 0,713 & 0,294 & Valid \\
\hline 25 & 0,649 & 0,294 & Valid \\
\hline
\end{tabular}

\subsubsection{Realibilitas Tes}

Berdasarkan hasil pengujian

$$
=\frac{13326-\frac{(706)^{2}}{45}}{45}
$$

reliabilitas tes adalah :

$$
=\frac{13326-11076,355}{45}
$$

Varians Total:

$$
\mathrm{S}^{2}=\frac{\sum x^{2}-\frac{\left(\sum x\right)^{2}}{n}}{n}
$$$$
=49,992
$$ 
Relibilitas dengan Rumus

$=\left(\frac{25}{24}\right)\left(\frac{44,2}{49,992}\right)=0,920$

KR.20

$$
\begin{aligned}
r_{11} & =\left(\frac{n}{n-1}\right)\left(\frac{s^{2}-\sum p q}{s^{2}}\right) \\
& =\left(\frac{25}{25-1}\right)\left(\frac{49,992-5,792}{49,992}\right)
\end{aligned}
$$

\subsubsection{Indeks daya beda dan indeks tingkat kesukaran}

TABEL 5

INDEKS DAYA BEDA DAN INDEKS TINGKAT KESUKARAN

\begin{tabular}{|l|l|l|r|}
\hline NO & \multicolumn{2}{|c|}{ Indeks Tingkat Kesukaran } & Indeks Daya Beda \\
\cline { 2 - 3 } & ITK & Ukuan
\end{tabular}

\begin{tabular}{|c|c|c|c|c|c|c|}
\hline & & & & & & \\
\hline 4 & 0,51 & $0,15-0,85$ & Layak & 0,85 & $\geq 0,20$ & Layak \\
\hline 5 & 0,62 & $0,15-0,85$ & Layak & 0,57 & $\geq 0,20$ & Layak \\
\hline 6 & 0,688 & $0,15-0,85$ & Layak & 0,58 & $\geq 0,20$ & Layak \\
\hline 7 & 0,666 & $0,15-0,85$ & Layak & 0,57 & $\geq 0,20$ & Layak \\
\hline 8 & 0,622 & $0,15-0,85$ & Layak & 0,5 & $\geq 0,20$ & Layak \\
\hline
\end{tabular}

\begin{tabular}{|c|c|c|c|c|c|c|}
\cline { 2 - 7 } & ITK & Ukuran & \multicolumn{1}{c|}{ Keterangan } & IDB & Ukuran & Keterangan \\
\hline 1 & 0,68 & $0,15-0,85$ & Layak & 0,35 & $\geq 0,20$ & Layak \\
\hline 2 & 0,6 & $0,15-0,85$ & Layak & 0,78 & $\geq 0,20$ & Layak \\
\hline 3 & 0,66 & $0,15-0,85$ & Layak & 0,57 & $\geq 0,20$ & Layak \\
\hline
\end{tabular}

\begin{tabular}{|c|c|c|c|c|c|c|}
\hline 9 & 0,688 & $0,15-0,85$ & Layak & 0,65 & $\geq 0,20$ & Layak \\
\hline 10 & 0,666 & $0,15-0,85$ & Layak & 0,78 & $\geq 0,20$ & Layak \\
\hline
\end{tabular}

\begin{tabular}{|c|c|c|c|c|c|c|}
\hline & & & & & & \\
\hline 13 & 0,711 & $0,15-0,85$ & Layak & 0,65 & $\geq 0,20$ & Layak \\
\hline 14 & 0,577 & $0,15-0,85$ & Layak & 0,79 & $\geq 0,20$ & Layak \\
\hline
\end{tabular}

\begin{tabular}{|c|c|c|c|c|c|c|}
\hline 11 & 0,622 & $0,15-0,85$ & Layak & 0,57 & $\geq 0,20$ & Layak \\
\hline 12 & 0,577 & $0,15-0,85$ & Layak & 0,64 & $\geq 0,20$ & Layak \\
\hline
\end{tabular}

\begin{tabular}{|c|c|c|c|c|c|c|}
\hline 15 & 0,622 & $0,15-0,85$ & Layak & 0,57 & $\geq 0,20$ & Layak \\
\hline 16 & 0,644 & $0,15-0,85$ & Layak & 0,72 & $\geq 0,20$ & Layak \\
\hline 17 & 0,555 & $0,15-0,85$ & Layak & 0,64 & $\geq 0,20$ & Layak \\
\hline 18 & 0,644 & $0,15-0,85$ & Layak & 0,65 & $\geq 0,20$ & Layak \\
\hline
\end{tabular}

\begin{tabular}{|c|c|c|c|c|c|c|}
\hline 17 & 0,555 & $0,15-0,85$ & Layak & 0,64 & $\geq 0,20$ & Layak \\
\hline 18 & 0,644 & $0,15-0,85$ & Layak & 0,65 & $\geq 0,20$ & Layak \\
\hline 19 & 0,644 & $0,15-0,85$ & Layak & 0,72 & $\geq 0,20$ & Layak \\
\hline 20 & 0,577 & $0,15-0,85$ & Layak & 0,79 & $\geq 0,20$ & Layak \\
\hline 21 & 0,622 & $0,15-0,85$ & Layak & 0,71 & $\geq 0,20$ & Layak \\
\hline 22 & 0,644 & $0,15-0,85$ & Layak & 0,71 & $\geq 0,20$ & Layak \\
\hline 23 & 0,644 & $0,15-0,85$ & Layak & 0,79 & $\geq 0,20$ & Layak \\
\hline 24 & 0,644 & $0,15-0,85$ & Layak & 0,78 & $\geq 0,20$ & Layak \\
\hline 25 & 0,66 & $0,15-0,85$ & Layak & 0,64 & $\geq 0,20$ & Layak \\
\hline
\end{tabular}

\subsection{Teknik Analisis Data}

\subsubsection{Teknik analisis data observasi}

Analisis data observasi dimaksudkan untuk mengukur tingkat persentase aktivitas siswa dalam proses pembelajaran. Dalam menganalisa hasil observasi atau pengamatan dilihat melalui dilaksanakan atau tidaknya aktivitas belajar tersebut oleh siswa selama proses pembelajaran berlangsung. 
Hasil observasi tersebut selanjutnya

dihitung dengan menggunakan rumus:

$$
N A=\frac{S}{S M} \times 100
$$

(Purwanto, 2009:102)
Keterangan :

NA : Nilai Akhir

S : Skor Observasi

SM : Skor Maksimal

Dengan kriteria tingkat keaktifan yaitu sebagai berikut:

TABEL 7

KRITERIA KEAKTIFAN SISWA

\begin{tabular}{|c|c|}
\hline Presentase \% & Keterangan \\
\hline $85-100$ & Sangat Aktif \\
\hline $69-84$ & Aktif \\
\hline $53-68$ & Cukup \\
\hline $37-52$ & Kurang \\
\hline$\leq 36$ & Sangat Kurang \\
\hline
\end{tabular}

\subsubsection{Teknik analisis data tes}

Untuk melihat tercapai atau tidaknya proses belajar mengajar dan keberhasilan siswa, ada kriteria yang harus dilihat dalam menilai hasil belajar.

TABEL 8

KATEGORI HASIL BELAJAR

\begin{tabular}{|c|c|}
\hline Nilai & Keterangan \\
\hline $86-100$ & Baik sekali \\
$71-85$ & Baik \\
$56-70$ & Cukup \\
$41-55$ & Kurang \\
$\leq 41$ & Sangat kurang \\
\hline
\end{tabular}

\subsection{Pengujian Hipotesis}

Pengujian hipotesis dalam melihat perbedaan hasil belajar ekonomi antara siswa yang belajar

penelitian ini adalah uji $\mathrm{t}$ dengan 
melalui pendekatan kontekstual dengan pendekatan konvensional.

Rumus yang dapat digunakan untuk-melakukan pengujian hipotesis dalam penelitian ini, ialah :

$t=\frac{X_{1}-X_{2}}{\sqrt{\frac{s_{1}^{2}}{n_{1}}+\frac{s_{2}^{2}}{n_{2}}}} \quad$ (Sugiono, 2007:138-139);

Rumus $t$ test ini dapat digunakan dengan syarat :

a. Bila jumlah anggota sampel $n_{1}$ $=\mathrm{n}_{2}$ dan varians homogen $\left(\sigma_{1}^{2}=\sigma_{2}^{2}\right)$, untuk mengetahui $\mathrm{t}$

Atau $t=\frac{X_{1}-X_{2}}{\sqrt{\frac{\left(n_{1}-1\right) S_{1}^{2}+\left(n_{2}-1\right) S_{2}^{2}}{n_{1}+n_{2}-2}\left[\frac{1}{n_{1}}+\frac{1}{n_{2}}\right]}}$

Rumus $\mathrm{t}$ test ini dapat digunakan dengan syarat :

a. Bila jumlah anggota sampel $n_{1}$ $=\mathrm{n}_{2}$ dan varians homogen $\left(\sigma_{1}^{2}=o_{2}^{2}\right)$, untuk mengetahui $\mathrm{t}$ tabel digunakan $\mathrm{dk}$ yang besarnya $\mathrm{dk}=\mathrm{n}_{1}+\mathrm{n}_{2}-2$.

b. Bila $\mathrm{n}_{1} \neq \mathrm{n}_{2}$, varians homogen $\left(\sigma_{1}^{2}=\sigma_{2}^{2}\right)$. Besarnya $\mathrm{dk}=\mathrm{n}_{1}+$ $\mathrm{n}_{2}-2$

c. Bila $\mathrm{n}_{1}=\mathrm{n}_{2}$, varians tidak homogen $\left(\sigma_{1}^{2} \neq \sigma_{2}^{2}\right)$ tabel digunakan $\mathrm{dk}$ yang besarnya $\mathrm{dk}=\mathrm{n}_{1}+\mathrm{n}_{2}-2$.

b. Bila $\mathrm{n}_{1}=\mathrm{n}_{2}$, varians tidak homogen $\left(\sigma_{1}^{2} \neq \sigma_{2}^{2}\right)$

c. Bila $\mathrm{n}_{1} \neq \mathrm{n}_{2}$ dan varians tidak homogen $\left(\sigma_{1}^{2} \neq \sigma_{2}^{2}\right)$. Harga $\mathrm{t}$ sebagai pengganti harga $t$ tabel dihitung dari selisih harga $\mathrm{t}$ tabel dengan $\mathrm{dk}=\mathrm{n}_{1}-1 \mathrm{dan} \mathrm{dk}$ $=\mathrm{n}_{2}-1$, dibagi dua dan kemudian ditambah dengan harga $t$ yang terkecil.

\section{Hasil Penelitian Pembahasan}

\subsection{Hasil Penelitian}

\subsubsection{Deskripsi}

Pelaksanaan

\section{Penelitian}

Penelitian ini dilakukan di SMA Negeri 1 Lubai Kecamatan Beringin Kabupaten Muara Enim, pertemuan pertama dalam pelaksanaan penelitian ini dilakukan pre-test untuk mengetahui karakteristik awal peserta didik sehingga memudahkan peneliti untuk memberikan materi pembelajaran dalam proses pelaksanaan penelitian. Untuk 
selanjutnya penelitian dilaksanakan dengan cara satu kelas belajar menggunakan pendekatan kontekstual, sedangkan satu kelas lainnya belajar menggunakan pendekatan

konvensional.

\subsubsection{Deskripsi Data Observasi}

Pelaksanaan penelitian ini selain menggunakan instrumen tes, peneliti juga menggunakan lembar observasi. Lembar observasi digunakan untuk melihat keaktifan siswa selama proses pembelajaran dengan menggunakan pendekatan kontekstual dan pendekatan konvensional. Data yang terlampir diambil melalui lembar observasi dianalisa dengan empat langkah, yaitu: langkah pertama dengan pemberian tanda $(\sqrt{ })$ untuk deskriptor yang tampak dan bila tidak tampak tidak diberi tanda check pada tiap deskriptor dilembar observasi, langkah kedua dengan pemberian skor, langkah ketiga mengkonversikan skor yang telah diperoleh menjadi nilai keaktifan, dan langkah yang keempat mengkonversikan nilai keaktifan siswa ke dalam kategori sangkat aktif, aktif, cukup aktif, kurang aktif, dan sangat kurang aktif.
Hasil pengolahan data observasi diketahui bahwa presentase siswa yang sangat aktif pada kelas X.5 yang belajar dengan menggunakan pendekatan kontekstual mempunyai presentase sebesar $17,14 \%$ dengan jumlah siswa yang sangat aktif sebanyak 6 orang, dan yang tergolong dalam ruang lingkup aktif diketahui sebanyak 29 orang atau sama dengan $82,86 \%$ dari jumlah siswa kelas X.5 yang diobservasi. Begitu pun hasil pengolahan lainnya yang menyajikan rata-rata keaktifan siswa pada kelas X.2 belajar menggunakan pendekatan konvensional diketahui presentasi siswa yang sangat aktif hanya 3 orang atau sebesar 9,67\% dari jumlah siswa yang mengikuti pembelajaran, dan yang termasuk dalam kategori aktif cukup banyak yakni berjumlah 28 orang atau dengan presentase 90,33\% dari jumlah siswa yang mengikuti pembelajaran di kelas X.2. Jadi dapat disimpulkan bahwa tingkat keaktifan siswa antara penggunaan pendekatan kontekstual dengan pendekatan konvensional terdapat perbedaan, yakni presentase siswa yang sangat aktif lebih banyak pada kelas X.5 yang menggunakan pendekatan kontekstual 
daripada kelas X.2 yang menggunakan pendekatan konvensional.

\subsubsection{Deskripsi Data Tes}

Tes telah diberikan kepada sampel penelitian yakni kelas X.5 menggunakan pendekatan kontekstual dalam proses pembelajaran dengan jumlah siswa 35 orang serta X.2 menggunakan pendekatan konvensional dalam proses pembelajaran dengan jumlah siswa 31 orang.

Berdasarkan hasil tes diketahui bahwa jumlah siswa pada kelas X.5 yang mendapatkan nilai $86-100$ berjumlah 8 orang atau $22,86 \%$, siswa yang mendapatkan nilai 71-85 sebanyak 26 orang atau 74,28\%, dan frekuensi siswa yang memperoleh nilai 56-70 sebanyak 1 orang atau 2,86\%. Sedangkan pada kelas X.2 yang belajar menggunakan pendekatan konvensional frekuensi siswa yang mendapatkan nilai 86-100 berjumlah 3 orang atau 9,68\%, dan jumlah siswa yang memperoleh nilai 71-85 sebanyak 25 orang atau 80,64\%, siswa yang memperoleh nilai 56-70 berjumlah 3 orang atau 9,68\%, dan yang memperoleh nilai 41-55 berjumlah 1 orang atau 3,03\%. Jadi dari presentase nilai yang diperoleh dapat disimpulkan bahwa terdapat perbedaan hasil belajar siswa yang menggunakan pendekatan kontekstual dengan pendekatan konvensional.

\subsubsection{Analisis Data Observasi}

Berdasarkan deskripsi data observasi keaktifan belajar siswa yang menggunakan pendekatan kontekstual maupun pendekatan konvensional, maka dapat dianalisis seperti yang terlihat pada diagram berikut ini:

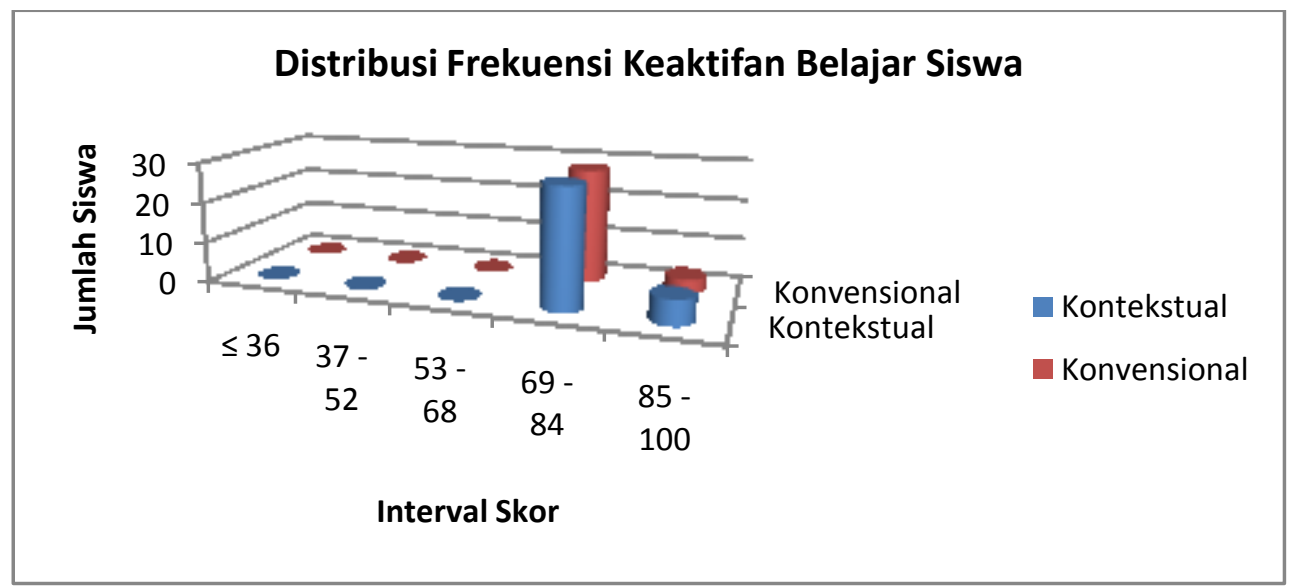


Berdasarkan gambar diagram di atas, diketahui bahwa tingkat keaktifan siswa yang belajar menggunakan pendekatan kontekstual dan pendekatan konvensional memiliki perbedaan, akan tetapi perbedaan keaktifan tersebut tidak begitu signifikan. Hal ini merupakan pembuktian bahwa meskipun pendekatan yang digunakan berbeda, tidak begitu banyak mempengaruhi keaktifan belajar siswa. Karena, siswa saat ini sudah terpola untuk berkompetisi, sehingga apa pun pendekatan yang digunakan tidak membuat siswa menjadi berhenti untuk berkompetisi.

\subsubsection{Analisis Data Tes}

Berdasarkan deskripsi tes yang dilakukan, diperoleh data bahwa hasil tes siswa yang merupakan hasil belajar siswa dengan menggunakan pendekatan kontekstual lebih baik dibandingkan dengan hasil belajar yang diperoleh siswa yang menggunakan pendekatan konvensional. Untuk lebih jelas mengenai perbedaan hasil yang diperoleh antara kedua pendekatan tersebut, maka dapat dilihat pada diagram di bawah ini:

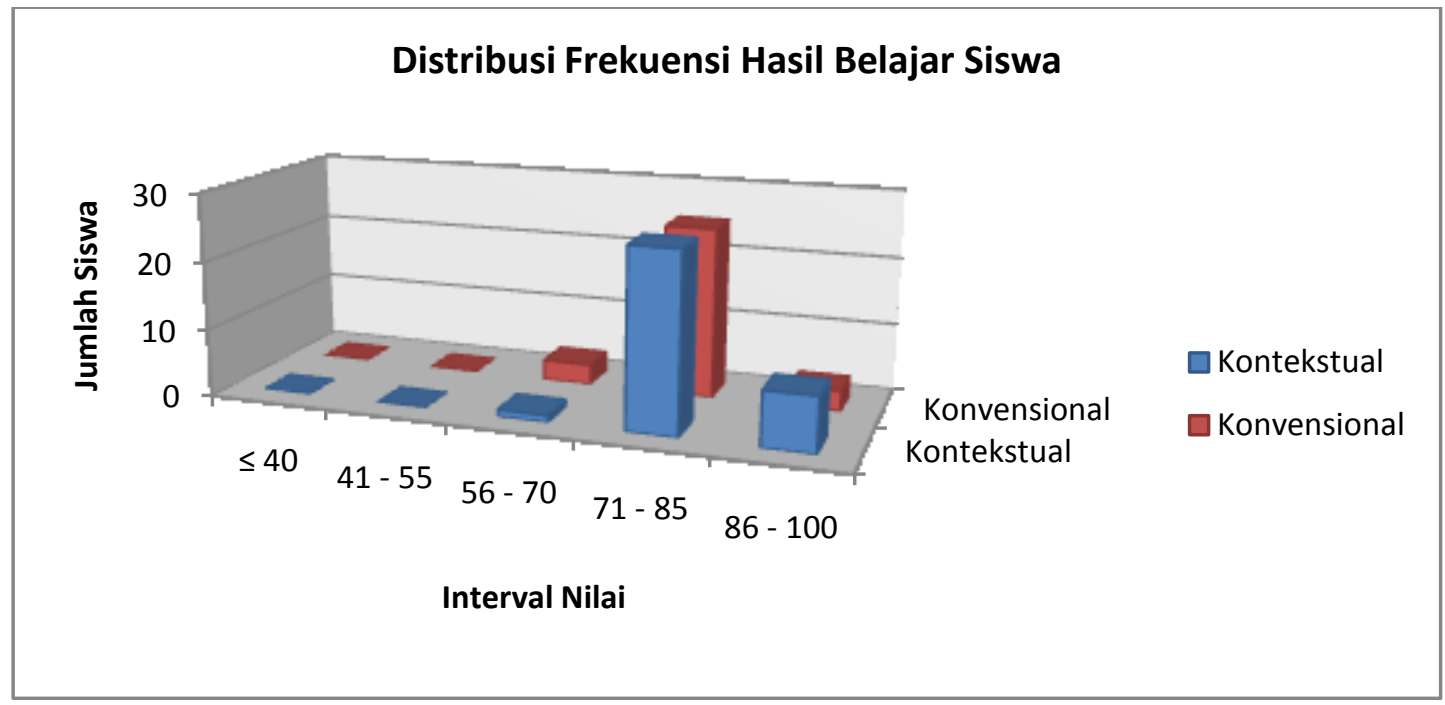

Berdasarkan gambar diagram tersebut, diketahui bahwa perbandingan hasil belajar siswa antara yang belajar menggunakan pendekatan kontekstual maupun pendekatan konvensional, memiliki perbedaan yang cukup signifikan pada interval 86 - 100 yang terkategori sangat baik, karena dalam 
pendekatan kontekstual jumlah siswa yang memperoleh predikat sangat baik lebih banyak daripada jumlah siswa yang belajar menggunakan pendekatan konvensional.

\subsubsection{Pengujian Hipotesis}

Pengujian hipotesis digunakan untuk menjawab permasalahan pada penelitian, dalam melakukan pengujian hipotesis ini menggunakan uji beda rata-rata dengan persamaan uji t. Langkah dalam melakukan pengujian hipotesis pada penelitian ini yaitu:

1) Hipotesis

$$
\begin{aligned}
& \text { Ho : } \mu_{1}=\mu_{2} ; \text { Tidak ada } \\
& \text { perbedaan hasil } \\
& \text { belajar siswa } \\
& \text { menggunakan } \\
& \text { pendekatan } \\
& \text { kontekstual dengan } \\
& \text { pendekatan } \\
& \text { konvensional pada } \\
& \text { mata pelajaran } \\
& \text { ekonomi di SMA } \\
& \text { Negeri } 1 \text { Lubai } \\
& \text { tahun pelajaran } \\
& 2015 / 2016
\end{aligned}
$$

menggunakan

pendekatan

kontekstual

dengan

pendekatan

konvensional

pada mata

pelajaran

ekonomi di

SMA Negeri 1

Lubai tahun pelajaran

$2015 / 2016$

2) Menentukan kriteria pengujian hipotesis

Kriteria pengujian hipotesis dalam penelitian ini adalah:

Ho ditolak bila $\mathrm{t}$ tabel $<\mathrm{t}$ hitung berarti terima $\mathrm{Ha}$

Ho diterima bila $\mathrm{t}_{\text {tabel }} \geq \mathrm{t}_{\text {hitung }}$ berarti tolak $\mathrm{Ha}$

3) Menentukan taraf uji signifikan dan nilai-nilai $t_{\text {tabel }}$

Taraf uji signifikan yang digunakan adalah $\alpha=0,05$ menggunakan uji 2 pihak dengan $\mathrm{dk}=$ $\mathrm{n}_{1}+\mathrm{n}_{2}-2$ yaitu $\mathrm{dk}=35+31-2=64$ diperoleh nilai $t_{\text {tabel }}$ sebesar 1,9900.

4) Menentukan nilai $t_{\text {hitung }}$

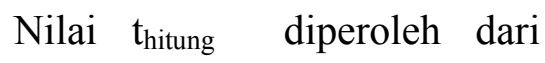
proses perhitungan dengan persamaan sebagai berikut: 


$$
t=\frac{X_{1}-X_{2}}{\sqrt{\frac{\left(n_{1}-1\right) S_{1}^{2}+\left(n_{2}-1\right) S_{2}^{2}}{n_{1}+n_{2}-2}\left[\frac{1}{n_{1}}+\frac{1}{n_{2}}\right]}}
$$

Berdasarkan lampiran 20 diketahui angka-angka sebagai berikut :

$$
\begin{aligned}
\sum \mathrm{X}_{1} & =2.910 \\
& \sum \mathrm{X}_{2}=2.475 \\
\sum \mathrm{X}_{1}{ }^{2} & =243.350 \\
& \sum \mathrm{X}_{2}^{2}=198.675 \\
\overline{\mathrm{X}}_{1} \quad=83,14 & \\
& \mathrm{X}_{2} \quad=79,84 \\
\mathrm{n}_{1} & =35 \quad \\
& \mathrm{n}_{2} \quad=31
\end{aligned}
$$

Dari data di atas, maka dapat dihitung komponen persamaan uji $t$, yaitu :

a) Perhitungan nilai varian atau

simpangan baku tiap variabel atau

$\mathrm{S}_{1}^{2}$ dan $\mathrm{S}_{2}^{2}$

Untuk menghitung $\mathrm{S}_{1}{ }^{2}$ adalah :

$$
\begin{aligned}
& S_{1}^{2}=\frac{n_{1} \sum X_{1}^{2}-\left(\sum X_{1}\right)^{2}}{n_{1}\left(n_{1}-1\right)} \\
& =\frac{35(243350)-2910^{2}}{35(35-1)}
\end{aligned}
$$

$$
t=\frac{X_{1}-X_{2}}{\sqrt{\frac{\left(n_{1}-1\right) S_{1}^{2}+\left(n_{2}-1\right) S_{2}^{2}}{n_{1}+n_{2}-2}\left[\frac{1}{n_{1}}+\frac{1}{n_{2}}\right]}}
$$

Maka $t$ hitung adalah sebagai berikut :

$$
t=\frac{X_{1}-X_{2}}{\sqrt{\frac{\left(n_{1}-1\right) S_{1}^{2}+\left(n_{2}-1\right) S_{2}^{2}}{n_{1}+n_{2}-2}\left[\frac{1}{n_{1}}+\frac{1}{n_{2}}\right]}}
$$

$S_{1}^{2}=\frac{8517250-8468100}{35(34)}$

$=\frac{8517250-8468100}{1190}$

$S_{1}^{2}=\frac{49150}{1190}=41,3$

Untuk menghitung $\mathrm{S}_{2}{ }^{2}$ adalah :

$S_{2}^{2}=\frac{n_{2} \sum X_{2}^{2}-\left(\sum X_{2}\right)^{2}}{n_{2}\left(n_{2}-1\right)}$

$=\frac{31(198675)-2475^{2}}{31(31-1)}$

$S_{2}^{2}=\frac{6158925-6125625}{31(30)}$

$=\frac{6158925-6125625}{930}$

$S_{2}^{2}=\frac{33300}{930}=35,81$

Jadi dapat diketahui bahwa $\mathrm{S}_{1}^{2}=$ 41,3 dan $\mathrm{S}_{2}^{2}=35,81$

b) Dari hasil perhitungan di atas, kemudian disubstitusikan ke dalam persamaan uji $t$ yait 


$$
\begin{aligned}
& t=\frac{83,14-79,84}{\sqrt{\frac{(35-1) 41,3+(31-1) 35,81}{35+31-2}\left[\frac{1}{35}+\frac{1}{31}\right]}} \\
& t=\frac{3,3}{\sqrt{\frac{1404,2+1074,3}{64}\left[\frac{66}{1085}\right]}} \\
& t=\frac{3,3}{\sqrt{\frac{2478,5}{64}\left[\frac{66}{1085}\right]}} \\
& =\frac{3,3}{\sqrt{38,73[0,06]}} \\
& t=\frac{3,3}{\sqrt{2,3238}}=\frac{3,3}{1,52}=2,171
\end{aligned}
$$

Dari perhitungan yang telah dilakukan maka diperoleh nilai thitung sebesar 2,171.

c) Kesimpulan Pengujian

Setelah diperoleh nilai $\mathrm{t}$ hitung dalam proses penelitian, kemudian membandingkan antara $t_{\text {hitung dengan }} t_{\text {tabel. }}$. Adapun perbandingan yang terlihat adalah $\mathrm{t}_{\text {hitung }}=2,171$ dan $\mathrm{t}_{\text {tabel }}=1,9900$. Dan diketahui bahwa $\mathrm{t}_{\text {tabel }}$ lebih kecil dari $t_{\text {hitung, berdasarkan }}$ kriteria pengujian yang telah ditetapkan maka kriteria pengujian yang telah dibuktikan adalah tolak Ho dan terima $\mathrm{Ha}$, yang berarti ada perbedaan hasil belajar siswa menggunakan pendekatan kontekstual dengan pendekatan konvensional pada

\subsection{Pembahasan}

Hasil analisis data di atas, maka dapat dijelaskan hasil penelitian yaitu mengenai data hasil observasi dan data hasil belajar ekonomi siswa yang menggunakan pendekatan kontekstual dengan pendekatan konvensional. Lembar observasi digunakan untuk melihat keaktifan siswa selama proses pembelajaran dengan menggunakan pendekatan kontekstual dan pendekatan konvensional.

Presentase keaktifan pada kelas X.5 yang belajar dengan menggunakan pendekatan kontekstual mempunyai presentase sebesar 17,14 $\%$ dengan jumlah siswa yang sangat aktif sebanyak 6 orang, dan yang tergolong dalam ruang lingkup aktif diketahui sebanyak 29 orang atau 
sama dengan $82,86 \%$ dari jumlah siswa kelas X.5 yang diobservasi. Sedangkan pada kelas X.2 yang belajar menggunakan pendekatan konvensional diketahui presentasi siswa yang sangat aktif hanya 3 orang atau sebesar 9,67\% dari jumlah siswa yang mengikuti pembelajaran, dan yang termasuk dalam kategori aktif cukup banyak yakni berjumlah 28 orang atau dengan presentase 90,33\% dari jumlah siswa yang mengikuti pembelajaran di kelas X.2. Jadi dari perbandingan yang terlihat dari presentase keaktifan siswa, maka dapat disimpulkan bahwa tingkat keaktifan siswa antara penggunaan pendekatan kontekstual dengan pendekatan konvensional terdapat perbedaan namun tidak signifikan, yakni presentase siswa yang sangat aktif lebih banyak pada kelas X.5 yang menggunakan pendekatan kontekstual daripada kelas X.2 yang menggunakan pendekatan konvensional. Hal ini memperlihatkan bahwa pendekatan kontekstual lebih tepat digunakan untuk meningkatkan keaktifan belajar siswa dibandingkan dengan pendekatan konvensional.

Hasil tes diketahui bahwa jumlah siswa pada kelas X.5 yang mendapatkan nilai $86-100$ berjumlah 8 orang atau $22,86 \%$ dan termasuk dalam kategori baik sekali, siswa yang mendapatkan nilai 71-85 sebanyak 26 orang atau $74,28 \%$ dan termasuk dalam kategori baik, dan frekuensi siswa yang memperoleh nilai $56-70$ sebanyak 1 orang atau 2,86\% termasuk dalam kategori cukup baik. Sedangkan pada kelas X.2 yang belajar menggunakan pendekatan konvensional frekuensi siswa yang mendapatkan nilai 86-100 berjumlah 3 orang atau 9,68\% termasuk dalam kategori sangat baik, dan jumlah siswa yang memperoleh nilai 71-85 sebanyak 25 orang atau $80,64 \%$ termasuk dalam kategori baik, siswa yang memperoleh nilai 56-70 berjumlah 3 orang atau 9,68\% termasuk dalam kategori cukup baik. Jadi dari presentase nilai yang diperoleh dapat disimpulkan bahwa terdapat perbedaan hasil belajar siswa yang menggunakan pendekatan kontekstual dengan pendekatan konvensional. Hal ini juga memperkuat bahwa pendekatan kontekstual lebih cocok digunakan dalam proses pembelajaran mata pelajaran ekonomi daripada pendekatan konvensional. 
Berdasarkan perbandingan dari pendekatan kontekstual dengan pendekatan konvensional diketahui perbandingan yang terlihat adalah $\mathrm{t}_{\text {hitung }}=2,171$ lebih besar dari $\mathrm{t}_{\text {tabel }}=$ 1,9900. Data-data yang diperoleh berdasarkan pengujian uji beda ratarata, hasil belajar dan keaktifan siswa sudah memperlihatkan bahwa pendekatan kontekstual adalah pendekatan yang lebih baik digunakan pada mata pelajaran ekonomi dibandingkan dengan pendekatan konvensional, karena pendekatan kontekstual mengajarkan siswa untuk memberikan solusi terhadap permasalahan yang terjadi secara langsung, hal ini juga didukung karena ekonomi merupakan suatu kegiatan yang telah dilakukan dan dilihat dalam kehidupan sehari-hari oleh siswa.

Khususnya pelajaran ekonomi dengan materi mengenai permintaan, penawaran, dan pasar sebaiknya guru menggunakan pendekatan kontekstual dalam proses pembelajaran, karena berdasarkan penelitian yang telah dilakukan pendekatan kontekstual memberikan tingkat keaktifan belajar lebih baik daripada pendekatan konvensional serta hasil belajar siswa yang menggunakan pendekatan kontekstual lebih baik daripada siswa yang belajar menggunakan pendekatan konvensional.

Kelemahan dalam penelitian ini adalah terletak pada sampel penelitian. Karena sampel yang diteliti dalam penelitian ini hanya terdiri dari 1 (satu) kelas yang menggunakan pendekatan kontekstual dan 1 (satu) kelas menggunakan pendekatan konvensional, sehingga hasil yang diperoleh seperti yang telah dijelaskan sebelumnya. Berdasarkan prediksi peneliti, hasil yang diperoleh mungkin akan lebih baik dan mewakili populasi jika sampel yang diteliti lebih banyak.

\section{Kesimpulan}

Penelitian ini bertujuan untuk mengetahui pendekatan yang lebih tepat digunakan dalam proses pembelajaran ekonomi. Hasil dari pengujian dan pelaksanaan penelitian menunjukkan bahwa diantara pendekatan kontekstual dan pendekatan konvensional, yang lebih tepat digunakan adalah pendekatan kontekstual. Hal ini dibuktikan dengan keaktifan siswa dalam belajar jika menggunakan pendekatan kontekstual setiap pertemuan mengalami peningkatan dibandingkan dengan 
pendekatan konvensional. Oleh karenanya, peneliti menyarankan kepada guru mata pelajaran ekonomi untuk melakukan pembelajaran menggunakan pendekatan kontekstual. Selanjutnya, hasil belajar siswa pun memperlihatkan perbedaan meskipun tidak begitu signifikan antara siswa yang belajar menggunakan pendekatan kontekstual dengan siswa yang belajar menggunakan pendekatan konvensional. Hal tersebut menunjukkan bahwa pendekatan kontekstual pun lebih tepat digunakan untuk meningkatkan hasil belajar siswa pada mata pelajaran ekonomi, faktor lain karena mata pelajaran ekonomi merupakan suatu kegiatan yang sudah akrab di kehidupan siswa.

Oleh karenanya, peneliti menyatakan bahwa pendekatan kontekstual merupakan pendekatan yang cocok untuk perkembangan belajar anak khususnya pada mata pelajaran ekonomi.

\section{DAFTAR PUSTAKA}

Arikunto, S. (2006). Prosedur penelitian suatu pendekatan praktik. Jakarta: PT. Rineka Cipta.

Dimyati. (2009). Belajar dan pembelajaran. Jakarta: PT. Rineka Cipta.

Hamalik, O. (2008). Proses belajar mengajar. Jakarta: PT. Bumi Aksara.

Hasbullah. (2009). Dasar-dasar ilmu pendidikan. Jakarta: PT. Raja Grafindo Persada.

Mulyatiningsih, E. (2012). Metode penelitian terapan bidang pendidikan. Bandung: Alfabeta.

Purwanto. (2009). Prinsip dan teknik evaluasi pengajaran. Bandung: PT. Remaja Rosdakarya.

Rusman. (2014). Model-model pembelajaran. Jakarta: PT. Raja Grafindo Persada.

Sagala, S. (2005). Konsep dan makna pembelajaran untuk membantu memecahkan problematika belajar dan mengajar. Bandung: CV. Alfabeta.

Sanjaya, W. (2011). Strategi pembelajaran berorientasi standar proses pendidikan. Jakarta: Prenada Media.

Sudjana, N. (2010). Penilaian hasil proses belajar mengajar. Bandung: PT. Remaja Rosdakarya.

Sugiono. (2008). Metode penelitian pendidikan. Bandung: $\mathrm{CV}$. Alfabeta. . (2011). Statistik untuk penelitian. Bandung: CV. Alfabeta Suryosubroto. (2009). Proses belajar mengajar di sekolah. Jakarta: Rineka Cipta.

Yamin. (2013). Paradigma baru pembelajaran. Jakarta: Referensi. 